University of Nebraska - Lincoln

DigitalCommons@University of Nebraska - Lincoln

Evaluating the role of EPA policy levers: An examination of a voluntary program and regulatory threat in the metal-finishing industry

Keith Brouhle

Grinnell College, brouhlek@grinnell.edu

Charles Griffiths

U.S. EPA

Ann Wolverton

U.S. EPA

Follow this and additional works at: https://digitalcommons.unl.edu/usepapapers

Brouhle, Keith; Griffiths, Charles; and Wolverton, Ann, "Evaluating the role of EPA policy levers: An examination of a voluntary program and regulatory threat in the metal-finishing industry" (2009). U.S. Environmental Protection Agency Papers. 159.

https://digitalcommons.unl.edu/usepapapers/159

This Article is brought to you for free and open access by the U.S. Environmental Protection Agency at DigitalCommons@University of Nebraska - Lincoln. It has been accepted for inclusion in U.S. Environmental Protection Agency Papers by an authorized administrator of DigitalCommons@University of Nebraska - Lincoln. 


\title{
Evaluating the role of EPA policy levers: An examination of a voluntary program and regulatory threat in the metal-finishing industry
}

\author{
Keith Brouhle ${ }^{\mathrm{a}, *}$, Charles Griffiths ${ }^{\mathrm{b}}$, Ann Wolverton ${ }^{\mathrm{b}}$ \\ a Department of Economics, Grinnell College, 1210 Park Street, Grinnell, IA 50112, USA \\ ${ }^{\mathrm{b}}$ US EPA, USA
}

\section{A R T I C L E I N F O}

\section{Article history:}

Received 19 January 2007

Available online 2 October 2008

\section{Keywords:}

Voluntary programs

Pollution control

Regulatory threat

Policy evaluation

\begin{abstract}
A B S T R A C T
In this paper, we evaluate the influence of two environmental policy levers on emissions in the metal-finishing industry: a voluntary program - the Strategic Goals Program (SGP) - and the threat of formal regulation. While voluntary approaches are increasingly utilized as policy tools, the effectiveness of such programs is often questioned, and the impact of a voluntary program in tandem with a regulatory threat is not well understood. We examine the decision to participate in the SGP and, conditional on that decision, determine the effects that the SGP and regulatory threat had on facility emissions behavior. Participation in the program appears related to several forms of external pressure: the regulatory threat, industry trade association membership, the level of environmental giving in a state, and a number of neighborhood characteristics. However, over the entire study period, participation in the SGP yielded little, if any, additional reductions in emissions, while the regulatory threat is correlated with significant emission reductions by both participants and non-participants. Splitting our study period into two time periods reveals a more nuanced relationship between SGP participation and emissions behavior than is evident over the entire study period. While participants do not appear to take advantage of the program initially, they make greater strides in reducing emissions than non-participants in later years. The split sample results also indicate that both participants and non-participants react strongly to the initial threat of regulation and to an increase in its relative stringency.
\end{abstract}

(c) 2008 Elsevier Inc. All rights reserved.

\section{Introduction}

Increasingly, regulators seek to provide adequate environmental protection at the lowest cost. This has led to the use of more flexible market-based and voluntary approaches to augment command-and-control regulatory approaches. Voluntary approaches, ranging from voluntary programs, environmental management systems, and labeling, have become increasingly popular as a way to enhance the efficacy and scope of existing regulations and to reduce emissions in sectors or for pollutants where formal environmental regulation is lacking. In this paper, we examine the influence of two environmental policy levers on emissions in the metal-finishing industry: a voluntary program—-the Strategic Goals

\footnotetext{
The views expressed in this paper are those of the authors and do not necessarily represent those of the US Environmental Protection Agency. This paper has not been subjected to EPA's review process and therefore does not represent official policy or views.

* Corresponding author. Fax: +16412694985.

E-mail address: brouhlek@grinnell.edu (K. Brouhle).
} 
Program (SGP) - and the threat of more formal regulation. We examine the decision to participate in the SGP and, conditional on that decision, determine the effects of the SGP and regulatory threat on facility emissions behavior. We also examine whether the effects of these policy levers on emissions behavior varies over time.

Since the introduction of EPA's first voluntary program in 1991, voluntary approaches have increasingly been used to address environmental issues in the US [5]. The literature posits a variety of reasons why firms may voluntarily participate in programs designed to reduce emissions beyond levels required by regulation. Voluntary measures may allow firms to reduce $\operatorname{costs}^{1}$ [4] or improve their environmental reputation with "green" consumers and investors [2,3,24]. A more cynical view argues that firms may engage in voluntary activities to provide a smokescreen for poor environmental performance [18]. It has also been argued that firms may act strategically, using the voluntary program to signal environmental responsibility to regulators in order to reduce the likelihood of future regulation $[9,29,32,35]$. How strongly this signal is conveyed may depend on the immediacy and severity of the threat. From the EPA's perspective, voluntary approaches are attractive if they lead to greater innovation [39] or achieve environmental objectives "more quickly and with lower costs" than regulatory approaches [37].

While there has been vigorous debate as to why voluntary approaches are used and their potential advantages over traditional policy tools, evidence of effectiveness has been mainly limited to EPA's large, multi-sector and climate-related voluntary programs. There is evidence that programs such as 33/50 and Green Lights were successful in reducing participant emissions $[21,23]$. However, studies find that EPA overstated progress toward environmental goals by failing to account for non-program factors, non-participant actions, and the ability to count prior reductions toward program goals $[8,13,14,23]$. Studies of other voluntary programs find less evidence of a discernible effect $[25,33,40]$. Welch et al. [40] report that the Climate Challenge Program did not result in participants improving environmental performance relative to others. In fact, there is evidence that participants performed worse than non-participants. Morgenstern et al. [33] find a temporary reduction in participants' fuel use as a result of Climate Wise, but this effect did not last past the initial years of the program.

Regulatory threats may also encourage improved environmental performance. Such changes in environmental performance may allow firms to better prepare themselves in the event that stricter regulations are imposed in the future. Moreover, improved environmental performance of the industry as a whole may decrease the likelihood and relative stringency of future regulation. To our knowledge, few papers empirically examine the role such a threat may play. When the threat is weak, abatement levels are likely to be lower than levels under regulation. When the threat of regulation is strong, cost savings and increases in social welfare are closer to levels achieved under optimal regulatory action $[34,35]$. Maxwell et al. [32] model a strategic game in which firms voluntarily reduce emissions in an attempt to preempt future regulation. Empirically, they find support for their hypothesis: firms voluntarily reduce toxic releases more rapidly in states with larger conservation membership, where the potential threat of regulation is higher. Henriques and Sadorsky [20] examine firms' environmental responsiveness more generally and find that regulatory pressure-both actual and anticipated-matters. Anton et al. [1] find that regulatory pressures do not directly impact emissions but do influence the type of environmental management systems adopted by firms.

In this paper, we examine emissions reductions in the metal-finishing industry at a time when the industry faced a credible regulatory threat but also had the opportunity to participate in a voluntary program, the SGP. Several characteristics of these policies make the metal-finishing industry an interesting case study. Firstly, unlike broad-based voluntary programs evaluated in the past, the SGP is a sector-based program that provides information and establishes goals that are tailored to a specific industry [10]. As a sector-based program, these goals were established through negotiation among multiple stakeholders, unlike many voluntary programs studied thus far. Secondly, the metal-finishing sector differs from many of the sectors that typically participate in voluntary programs (e.g., the chemical industry) in that it is characterized by small, single-facility firms, many of which are privately held. Thirdly, the nature of the regulatory threat changes over time, allowing us to compare the effect of the initial threat with one of relatively greater stringency. We first ask if the regulatory threat and other factors played a role in the decision to participate in the SGP. We then attempt to determine what effect, if any, the voluntary program and regulatory threat had on the pollution profile of facilities. ${ }^{2}$ Finally, we split the sample into two time periods to examine whether the SGP had initial success in encouraging greater emission reductions from participants, whether this difference in emissions eroded over time, and whether a change in the nature of the regulatory threat over the study period affected emissions behavior.

\section{Metal finishing: the Strategic Goals Program and threat of regulation}

The origin of the EPA's SGP can be traced to the Common Sense Initiative (CSI). Launched in 1994, the CSI was a consensus-based, multi-stakeholder initiative designed to identify "cleaner, cheaper, and smarter" sector-based approaches

\footnotetext{
${ }^{1}$ Lower costs may arise directly from a voluntary program or measure (e.g., the use of energy-efficient lighting in Green Lights) or indirectly (e.g., reducing a firm's environmental risk may lower insurance premiums). Environmentally friendly firms may also find it easier to raise capital if environmental performance results in higher stock market valuations [17,27].

2 We examine the impact of the SGP on the total pounds of a facility's emissions. In the appendix of the paper, available through JEEM's online archive of supplementary material at http://www.aere.org/journal/index.html, we examine the impact of the SGP on toxicity-weighted emissions. Our key findings are robust to this alternate specification.
} 
to protect human health and the environment in six industries, one of which was metal finishing [11]. Rather than rely on strict guidelines and command-and-control regulations for specific media (e.g., air, water), the premise of the initiative was that firms would find cheaper, more innovative ways to reduce environmental impacts if they were given flexibility to address pollution control.

This appeal was further enhanced when the metal-finishing industry came under threat of regulation. First introduced in 1995, the Effluent Limitations Guidelines and New Source Performance Standards for the Metal Products and Machinery Point Source Category (or the MP\&M regulation) sought to impose new effluent guidelines and pretreatment standards for wastewater discharges from metal products and machinery facilities. The MP\&M regulation was re-proposed in 2001 to apply to a wider range of sectors and with more stringent limits than in 1995. It was made final in 2003, though the metalfinishing industry was exempted from the final regulation. ${ }^{3}$ However, over our study period the threat of regulation to the metal-finishing industry was quite real. ${ }^{4}$

With the MP\&M regulatory threat in the background, the CSI began developing the SGP in 1996. Much of the stakeholder negotiation on the nature of the program was completed that year. The regulatory threat is mentioned as one reason why stakeholders succeeded in reaching consensus [22]. The SGP was launched by the EPA along with several industry trade organizations at the end of $1997 .{ }^{5}$ Within a year, the program had over 250 participants. By the program's end in 2002, 550 facilities had joined the SGP, with most new participants joining in 2000 or after.

The SGP provided an industry-specific way in which the more general objective of the CSI could be met. It encouraged companies "to go beyond environmental compliance" through the achievement of seven specific goals: 50\% reduction in water usage, $25 \%$ reduction in energy use, $90 \%$ reduction in organic TRI releases, 50\% reduction in metals released to water and air (as reported to TRI), 50\% reduction in land disposal of hazardous sludge, 98\% metals utilization, and reduction in human exposure to toxic materials in the facility and surrounding community [36]. Facilities that joined the SGP committed to accomplishing these goals by 2002. The achievement of these goals was measured against a 1992 baseline. When facilities joined the SGP, they were asked to estimate baseline emissions, using 1992 or an alternate year if these data were unavailable.

To encourage facilities to join and to help them meet program goals, the SGP established the National Metal Finishing Resource Center (NMFRC) to act as a clearinghouse for technical information and a place where participants could seek assistance in improving environmental performance. The NMFRC collected annual surveys to track environmental performance of SGP members, determined if facilities had met program goals, and provided online access to a feature comparing a member's performance to that of other participants. ${ }^{6}$ By identifying areas where facilities scored poorly, the hope was that they would learn where to focus efforts to improve in the future. The SGP also offered free, non-regulatory environmental audits, on-site technical assistance, funding for environmental technologies, free workshops on energy, water and waste reduction, environmental management system (EMS) training, and free interns to help facilities fill out paperwork associated with the program. While some technical and regulatory information was publicly available from NMFRC, access to a detailed technical database, performance evaluations and free, hands-on assistance were made available only to participants.

The metal-finishing industry is a good candidate for assessing the effect of two environmental policy levers: a voluntary program (the SGP) and a credible regulatory threat (MP\&M regulation). The regulatory threat was real and immediate; the SGP set explicit targets; annual reporting and environmental performance comparisons allowed participants to monitor progress relative to a baseline and to identify areas for improvement; and an independent, third-party organization (NMFRC) provided technical assistance and information to SGP members. We seek to explore three questions with regard to these policy levers: What factors affected a facility's decision to participate in the voluntary SGP? What factors affected facility TRI air emissions, and did the SGP and MP\&M regulatory threat play a role in affecting those emissions? Did the effects of the SGP and the MP\&M regulatory threat on emissions change over time?

\section{Empirical model}

To the extent that firms derive net benefits from a voluntary program, they will join. The extent to which this translates into real behavioral change (i.e., reductions in emissions) must also be directly associated with the derivation of positive net benefits, since firms will incur additional costs to make these changes. We present a modeling framework in this section to examine factors associated with the decision to join and with emissions changes.

We first model the facility's net benefit from participation $D_{i t}^{*}$ in the voluntary program

$$
D_{i t}^{*}=\beta_{1} X_{1 i t}+\varepsilon_{1 i t},
$$

where $X_{1 i t}$ is a vector of exogenous variables for the $i$ th firm at time $t, \beta_{1}$ is a vector of parameters, and $\varepsilon_{1 i t}$ is a random error term. Since the net benefits of participating, $D_{i t}^{*}$, are not observed, we proxy for this with the observed participation

\footnotetext{
${ }^{3}$ In February 2003, EPA announced that it would exempt the metal-finishing industry from the final MP\&M regulation due to economic infeasibility; analysis showed that half of the metal-finishing job shops would close due to the regulation.

${ }^{4}$ The 2001 proposed rule argued that excluding the industry was not appropriate.

5 They are the National Association of Metal Finishers (NAMF), American Electroplaters and Surface Finishers Society (AESF), Metal Finishing Suppliers Association (MFSA), and Surface Finishing Industry Council (SFIC).

${ }^{6}$ These data are not shared with the US EPA in a way that allows for facility identification.
} 
decision of the facility, $D_{i t}$ :

$$
\begin{array}{ll}
D_{i t}=1 & \text { if } D_{i t}^{*}>0 \\
D_{i t}=0 & \text { otherwise. }
\end{array}
$$

This allows us to estimate

$$
D_{i t}=F\left(\beta_{1} X_{1 i t}\right)+\mu_{i t} .
$$

If $F(\cdot)$ is the cumulative distribution of the standard normal variate $\varepsilon_{1 i t}$, then Eq. (3) can be estimated using the probit model.

Next, we characterize the pollution level of facility $i$ at time $t$ as

$$
Y_{i t}=\alpha D_{i t}+\beta_{2} X_{2 i t}+\varepsilon_{2 i t},
$$

where $Y_{i t}$ is the pollution level, $D_{i t}$ is SGP participation, $X_{2 i t}$ is an exogenous facility-specific variable vector, $\alpha$ is a parameter, $\beta_{2}$ is a vector of parameters, and $\varepsilon_{2 i t}$ is a random error term.

To examine whether the SGP affected facility emission behavior, we examine how pollution levels change over the time period for which the SGP was in place:

$$
\Delta Y_{i t}=\alpha \Delta D_{i t}+\beta_{2} \Delta X_{2 i t}+\Delta \varepsilon_{2 i t},
$$

where $\Delta$ is the change in the variable between time period $t$ and $t-1$. We examine the change in facility emissions over the entirety of the SGP to determine the long term impact of the program as well as factors such as the regulatory threat. We also divide the sample in half to examine how the effects of different factors on emissions might have changed over time.

Estimation of Eq. (5) may lead to biased estimates if the participation variable, $D_{i t}$, is not exogenous. Facilities that receive the most benefits from the SGP_be that cover from regulatory threat or increased flexibility to reduce emissions-may also be most likely to join the SGP. We test for bias and use an instrumental variable approach instead of letting participation directly enter Eq. (5). To implement the instrument approach, we first separately estimate the participation decision in Eq. (3) using a probabilistic choice model to obtain consistent estimates of $\hat{\beta}_{1}$. We then estimate the predicted probability of participation, $\hat{D}_{i t}=F\left(\hat{\beta}_{1} X_{1 i t}\right)$. Finally, we use the predicted probability of participation as an instrument in Eq. (5). Through this estimation procedure, the final estimates of $\alpha$ and $\beta_{2}$ are consistent [19,23,40].

\section{Data}

To evaluate the SGP and MP\&M regulatory threat, we create a unique dataset from a variety of sources, including EPA's Toxic Releases Inventory (TRI), Enforcement and Compliance History Online (ECHO), Resource Conservation and Recovery Act Information database (RCRIS), and Green Book. We limit our study to facilities reporting emissions to TRI in the metalfinishing industry (SIC 3471) in the continental United States. ${ }^{7}$ Since three of the SGP's seven goals relate to TRI emissions (90\% reduction in organic TRI releases, $50 \%$ reduction in metals released to water and air, and reduction in human exposure to toxic materials in the facility and surrounding community), these data should provide a useful measure of the relative progress of members and non-members. To these data, we add information on participation in the SGP, a trade group, and other voluntary agreements; state-level dues and contributions to environmental organizations; a state-level regulatory stringency index [28]; neighborhood socioeconomic characteristics; and facility-specific information from InfoUSA. We drop facilities that were late joiners of the SGP in 2000 or 2001, since there may have been insufficient time to achieve significant emission changes before the program ended in 2002. In total we have 199 facilities in our data set, 65 of which are SGP members. ${ }^{8}$ Our sample of SGP participants represents approximately $25 \%$ of the total SGP population that signed up to participate prior to 2000 .

\subsection{Variables}

We estimate two main types of regression equations, one that examines what factors affect facility participation in the SGP and one that examines what factors affect facility emissions behavior. The dependent variable for the participation equation is defined as SGP, equal to 1 if the facility joined the SGP and 0 otherwise. The dependent variable for the emissions equation compares average air emissions prior to the start of the SGP to just after the end of the program. ${ }^{9}$

\footnotetext{
${ }^{7}$ Facilities that have fewer than 10 full-time employees, manufacture less than 25,000 pounds or use less than 10,000 pounds of a listed chemical do not have to report to the TRI. While the metal-finishing industry is mostly comprised of small establishments- $50 \%$ have less than 10 employees according to the US Census - there are more than 500 facilities that report to the TRI in a given year. Because chemicals are added and deleted from the TRI over time, we only retain chemicals reported to the TRI over the entire study period.

${ }^{8}$ Two observations were dropped due to extreme changes in emissions over time, which we believe are likely due to mistakes in paperwork or data entry, or inconsistency in the estimation method used. Average emissions for non-participants are considerably lower without the two observations, though the main regression results are unaffected.

${ }^{9}$ We considered using total air plus surface water emissions. However, about $89 \%$ of facilities in our dataset report zero and $95 \%$ report 10 or fewer pounds of surface water emissions in 1995. The correlation coefficient between total air and surface water emissions is 0.99 .
} 
Table 1

Summary of independent variables by equation

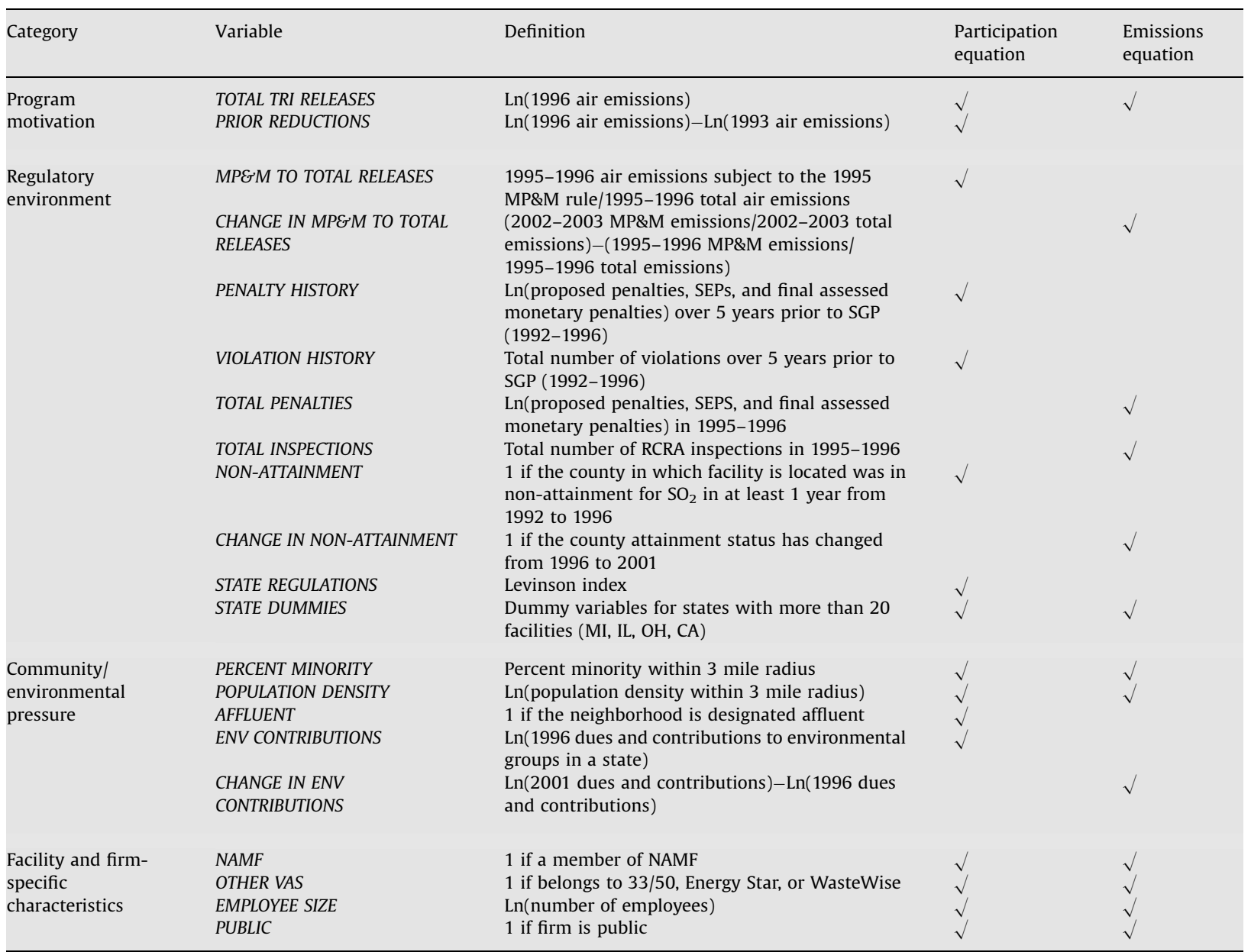

Specifically, CHANGE IN TRI EMISSIONS is defined at the facility level as the difference between the log of average total TRI air emissions in 2002-2003 and the log of average total TRI air emissions in 1995-1996. In addition to total air emissions, we also define the dependent variable in terms of point air emissions to examine the robustness of our results. We do not rely on the difference between single-year emissions (e.g., 2003-1996) for the dependent variable because we want to limit the impact of year-to-year fluctuations in emissions that may result from changes in estimation techniques and reporting errors [12].

In Eq. (5) of the empirical model, the emissions regression includes SGP participation as an independent variable. We include the predicted probability of joining SGP as an instrument for participation. Because many factors that affect a facility's net benefits from joining the SGP also affect emissions, the vectors $X_{1 i t}$ and $X_{2 i t}$ contain many of the same explanatory variables. The predicted probability of joining the SGP helps to separate out the effects of these variables on participation and emissions. The independent variables affecting participation and emissions fall into four categories: program motivation, regulatory environment, community and environmental pressures, and firm and facility-specific characteristics. Table 1 lists the variables and indicates in which equation they appear.

Facilities that are relatively clean may be more dedicated to environmental goals and therefore more likely to join the program and to subsequently reduce emissions. On the other hand, relatively dirty facilities may join to improve their reputation through association with an environmental program without necessarily changing behavior drastically. To capture these possible effects, we include TOTAL TRI RELEASES, defined as the log of total air emissions in 1996, in both the participation and emissions reductions equations. ${ }^{10}$ Participation in the SGP may also depend on the ease with which a facility can meet program goals. Since the SGP allowed facilities to benchmark pollution to 1992 levels rather than to the level of pollution at the time the facility joined the program, facilities that had already made reductions could join and, with little change in behavior, point to progress toward SGP goals. We therefore create a variable PRIOR REDUCTIONS to

\footnotetext{
${ }^{10}$ When we use point air emissions for the dependent variable, we define these variables as point air emissions.
} 
measure the reductions in releases prior to the start of the program: the difference between the log of 1996 air emissions and the log of 1993 air emissions. ${ }^{11}$ We include this variable only in the SGP participation equation.

Differences in regulatory environment may also affect decisions about whether to participate in the SGP and how much to reduce emissions. The existing literature emphasizes the importance of regulatory pressure to encourage real environmental actions [20,31,34,35]. The MP\&M rule acted as a viable, potential regulation over this time period (see Section 2). While the MP\&M rule pertains to water effluent discharges, air emissions are often generated through the same processes from the use of solvents, acids, and metals in surface preparation, plating, and finishing. To the extent that facilities look for ways to reduce wastewater discharges through input substitution, pollution prevention, or metal recovery processes, they also likely reduce air emissions. To capture the effect of potential regulation on the propensity of an individual facility to join the SGP, we calculate MPEM TO TOTAL RELEASES as the proportion of a facility's 1996 TRI air emissions subject to the 1995 proposed MP\&M rule. This variable ranges from zero to one: the closer to one, the more potentially vulnerable is a facility to regulation. For the emissions equation, we define CHANGE IN MPEM TO TOTAL RELEASES as the difference between the proportion of total releases potentially subject to the 1995 and 2001 MP\&M rules in 2002-2003 and the proportion of total releases subject to these rules in 1995-1996. Negative values indicate that a greater proportion of emission changes occurred in chemicals under regulatory threat, reflecting a possible attempt to make the facility less vulnerable to regulation over time. ${ }^{12}$

Facilities that have been out of compliance with environmental regulations may have an incentive to improve environmental performance to reduce EPA scrutiny. We use several measures of non-compliance. For the participation equation, we use the 5-year enforcement history prior to when a facility decided whether to join the SGP: PENALTY HISTORY is the log of the total assessed penalties between 1992 and 1996, and VIOLATION HISTORY is the total number of violations between 1992 and $1996 .^{13}$ For the emissions equation, we use TOTAL PENALTIES, the log of all financial penalties imposed in 1995 and 1996, and TOTAL INSPECTIONS, the total number of RCRA inspections in 1995 and 1996, to represent regulatory attention in the period immediately prior to the start of the program. We do not use changes in penalties or inspections over time since they are likely endogeneous with changes in emissions.

We capture differences in regulatory environment across location through county attainment status with the National Ambient Air Quality Standard for sulfur dioxide $\left(\mathrm{SO}_{2}\right)$ and stringency of state regulations. Counties in non-attainment face greater scrutiny and are required to implement specific plans and regulations to work toward future compliance. For the participation equation, we use a dummy variable, NON-ATTAINMENT, to indicate whether a facility is located in a county out of attainment with federally mandated levels for $\mathrm{SO}_{2}$ air emissions in years prior to the SGP (1992-1996). For the emissions equation, we use CHANGE IN NON-ATTAINMENT, equal to 1 if a county's attainment status changed between 1996 and 2002. ${ }^{14}$ An index from Levinson [28], STATE REGULATIONS, captures relative stringency of environmental regulations across states. Since the index is only available at the beginning of our study period (1991-1993), it is only included in the participation equation. We also define a set of dummy variables to capture other differences in states with a large concentration of metal-finishing facilities (IL, CA, OH, and MI).

To capture potential differences in community pressure, we use PERCENT MINORITY and log of POPULATION DENSITY in a three mile radius around the facility. We also include AFFLUENT, a dummy variable that indicates whether a facility is in an affluent neighborhood. The environmental justice literature finds that hazardous waste facilities are located in poorer, more diverse, and less dense communities [15]. In addition, Hamilton [16,17] shows that hazardous waste handlers consider the potential for community-led political action in expansion decisions. Thus, we also measure the environmental pressure a facility may face by using total environmental dues and contributions by state collected annually by the National Center for Charitable Statistics of the Urban Institute. For the participation equation, we use ENV CONTRIBUTIONS, the log of 1996 environmental dues and contributions. For the emissions equation, we use the CHANGE IN ENV CONTRIBUTIONS, which is the difference in the log of total dues and contributions in 2001 (the last year for which we have data) and 1996.

Firm and facility-specific characteristics may also influence a facility's decision to join the SGP or its emissions behavior. Since the SGP was launched with the support of the National Association of Metal Finishers (NAMF), we expect that trade association members are more familiar with the program and hence more likely to join. Also, to the extent that poor environmental performance by a subset of facilities casts a negative image on the industry as a whole, NAMF may have an interest in promoting the SGP [26]. We identify whether the firm belongs to the trade association with the dummy variable $N A M F$. We also identify firms that belong to 33/50, Energy Star, or WasteWise voluntary programs with the dummy variable OTHER VAS. Participation in one voluntary program may lead to participation in others [2,38] and may predispose a facility toward greater emission reductions.

\footnotetext{
${ }^{11}$ We did not define this as the difference in 1992 and 1996 emissions because we want to balance missing observations in the early years with the ability to capture past emission reductions that count as progress in the SGP. For facilities with missing emissions data in 1993, we explore two options: assume that emissions are zero or drop the observations.

12 We explored an alternate definition to capture the threat of regulation in the emissions equation, the difference in logs of average emissions under threat from MP\&M in 1995-1996 and 2002-2003. We found our results are robust to this alternate definition.

${ }^{13}$ RCRIS also has total number of inspections and enforcement actions, which are highly correlated with total violations. The literature is unclear about which of these might be a better measure of past enforcement behavior.

${ }^{14}$ No county that was in attainment in 1992 went out of attainment in later years. A noticeable number of counties have gone from non-attainment to attainment. In 1996, 29 facilities were in counties out-of-attainment for $\mathrm{SO}_{2}$. In 2003, 20 were in non-attainment counties.
} 
Table 2

Average total air emissions in SIC 3471

\begin{tabular}{|c|c|c|c|c|c|c|c|c|c|}
\hline \multirow[t]{2}{*}{ Year } & \multicolumn{3}{|c|}{ Total sample (199 facilities) } & \multicolumn{3}{|c|}{ SGP participants (65 facilities) } & \multicolumn{3}{|c|}{ Non-participants (134 facilities) } \\
\hline & Mean & $\begin{array}{l}\text { Standard } \\
\text { deviation }\end{array}$ & $\begin{array}{l}\text { Coefficient of } \\
\text { variation }\end{array}$ & Mean & $\begin{array}{l}\text { Standard } \\
\text { deviation }\end{array}$ & $\begin{array}{l}\text { Coefficient of } \\
\text { variation }\end{array}$ & Mean & $\begin{array}{l}\text { Standard } \\
\text { deviation }\end{array}$ & $\begin{array}{l}\text { Coefficient of } \\
\text { variation }\end{array}$ \\
\hline 1995 & 7719 & 43,192 & 5.60 & 3464 & 7782 & 2.25 & 9805 & 52,294 & 5.33 \\
\hline 1996 & 6848 & 26,635 & 3.89 & 4595 & 10,827 & 2.36 & 7964 & 31,556 & 3.96 \\
\hline 2002 & 4787 & 19,445 & 4.06 & 3472 & 7816 & 2.25 & 5446 & 23,068 & 4.24 \\
\hline 2003 & 3924 & 12,914 & 3.29 & 3214 & 7108 & 2.21 & 4290 & 14,951 & 3.49 \\
\hline
\end{tabular}

Coefficient of variation $=$ standard deviation $/$ mean .

Figures are in pounds of releases.

Source: Toxic Release Inventory.

Compositionally, these facilities are somewhat similar in what they produce (they are all from SIC 3471). However, facility-specific information such as size, production level, and technology may be important in predicting environmental behavior. For instance, larger facilities may be more visible and hence under more pressure from consumers, shareholders, and regulators $[2,40]$, or they may be more environmentally responsive if economies of scale exist in implementing environmental protection activities [6]. Unfortunately, since most firms in the metal-finishing industry are private, detailed financial data are not available. From InfoUSA, we include the log of the number of employees at the facility, EMPLOYEE SIZE, and a dummy variable, PUBLIC, to indicate whether a facility is publicly or privately held.

\subsection{Summary statistics}

According to the US Census of Manufacturers, there were 3401 establishments in the metal-finishing industry (SIC code 3471 ) in 1997, 97\% of which were single-facility firms. In 1996, 771 facilities from the metal-finishing industry submitted full reports to the TRI. Our sample consists of 199 metal-finishing facilities. These facilities reported to the TRI in all study years and were present in other datasets utilized for the study. The facilities in our sample are located in 40 of 48 states. Illinois, Michigan, Ohio, and California account for almost half of the facilities. Data from the US Census of Manufacturers confirm that this distribution is broadly representative of the industry ( $42 \%$ of the industry is located in one of these four states).

Summary statistics in Table 2 indicate that total air emissions for metal finishers reporting to TRI have declined by $49 \%$ over the study period to an average of 3924 pounds per facility in 2003. SGP participants experienced a moderate $7 \%$ decline in emissions over the same time period. While SGP facilities achieved smaller reductions, participants emitted substantially less air pollution than non-participants on average in each year of the study period. As expected, the difference in average emissions between participants and non-participants decreased over time, given the more rapid decline in non-participant emissions. There also appears to be less variance in SGP participant emissions. This is confirmed when we calculate the coefficient of variation for SGP and non-SGP facilities (see Table 2).

We investigate the wide disparity between participants and non-participants in the earlier years by looking at 1996 average total air emissions by quintile (see Table 3). Not surprisingly, large emitters dominate the average and thus the overall difference in emissions between participants and non-participants: Non-participants in the last quintile emit about twice as much, on average, as participants. What is not apparent from Table 2 is that this relationship does not characterize the remaining quintiles. The first three quintiles, the relatively clean facilities, look quite similar across participants and non-participants. For the fourth quintile, participants actually emit almost twice as much as non-participants.

Table 4 presents summary statistics for the independent variables in the participation and emissions equations. SGP participants tend to have a higher proportion of MP\&M releases. While both participants and non-participants tend to decrease their share of MP\&M releases, participants decrease this proportionally more than non-participants. SGP participants also tend to have lower penalties but almost the same number of violations as non-participants. They also tend to increase emissions prior to the SGP, while non-participants tend to decrease emissions. Finally, SGP participants tend to have fewer employees; be members of NAMF; belong to other voluntary agreements; and be located in states where environmental groups receive greater dues and contributions, counties that are in non-attainment prior to SGP, and affluent neighborhoods.

\section{Results}

We present results from several sets of regressions that are designed to address the three questions identified above. 
Table 3

Average total air emissions in SIC 3471 by quintile for 1996

\begin{tabular}{lrr}
\hline Quintile & SGP participants (65 facilities) & Non-participants (134 facilities) \\
\hline 1 & 5 & 4 \\
2 & 102 & 118 \\
3 & 495 & 484 \\
4 & 2287 & 1391 \\
5 & 19,859 & 38,969 \\
\hline
\end{tabular}

Note that a participant quintile consists of 13 observations while a non-participant quintile consists of approximately 27 observations.

Table 4

Summary statistics

\begin{tabular}{|c|c|c|c|c|c|c|}
\hline \multirow[t]{2}{*}{ Continuous variables } & \multicolumn{2}{|c|}{$\begin{array}{l}\text { Total sample (199 } \\
\text { facilities) }\end{array}$} & \multicolumn{2}{|c|}{$\begin{array}{l}\text { SGP participants ( } 65 \\
\text { facilities) }\end{array}$} & \multicolumn{2}{|c|}{$\begin{array}{l}\text { Non-participants ( } 134 \\
\text { facilities) }\end{array}$} \\
\hline & Mean & $\begin{array}{l}\text { Standard } \\
\text { deviation }\end{array}$ & Mean & $\begin{array}{l}\text { Standard } \\
\text { deviation }\end{array}$ & Mean & $\begin{array}{l}\text { Standard } \\
\text { deviation }\end{array}$ \\
\hline TRI emissions in 1996 (pounds) $^{\mathrm{a}, \mathrm{b}}$ & 6848 & 26,635 & 4595 & 10,827 & 7964 & 31,556 \\
\hline Change in TRI emissions from 1993 to 1996 (pounds) & -978 & 30,688 & 2497 & 9049 & -2664 & 36,794 \\
\hline $\begin{array}{l}\text { MP\&M emissions in } 1995-1996 \text { divided by total emissions } \\
\text { in } 1995-1996^{b}\end{array}$ & 0.39 & 0.46 & 0.43 & 0.47 & 0.38 & 0.46 \\
\hline $\begin{array}{l}\text { Change in MP\&M emissions to total emissions from } \\
1995-1996 \text { to } 2002-2003^{b}\end{array}$ & -0.03 & 0.32 & -0.05 & 0.34 & -0.01 & 0.31 \\
\hline Number of penalties from 1992 to $1996^{a}$ & $\$ 2045$ & $\$ 12,838$ & $\$ 946$ & $\$ 6857$ & $\$ 2577$ & $\$ 14,895$ \\
\hline Number of violations from 1992 to 1996 & 2.19 & 3.70 & 2.17 & 3.73 & 2.19 & 3.70 \\
\hline Levinson index & 0.94 & 0.18 & 0.94 & 0.18 & 0.94 & 0.18 \\
\hline Percent minority within a 3 mile radius & 0.37 & 0.26 & 0.35 & 0.25 & 0.37 & 0.26 \\
\hline Population density within a 3 mile radius ${ }^{a}$ & 4709 & 4781 & 4718 & 3487 & 4705 & 5308 \\
\hline Total environmental group contributions in 1996 (millions) $^{a}$ & $\$ 46.0$ & $\$ 60.8$ & $\$ 59.8$ & $\$ 71.4$ & $\$ 39.4$ & $\$ 53.9$ \\
\hline $\begin{array}{l}\text { Change in environmental group contributions, 1996-2001 } \\
\text { (millions) })^{\mathrm{a}}\end{array}$ & $-\$ 5.5$ & $\$ 24.2$ & $-\$ 6.9$ & $\$ 3.1$ & $-\$ 4.8$ & $\$ 20.0$ \\
\hline Number of employees ${ }^{a}$ & 91 & 101 & 86 & 65 & 93 & 114 \\
\hline Dummy variables & \multicolumn{2}{|c|}{$\begin{array}{l}\text { Total sample (199 } \\
\text { facilities) }(\%)\end{array}$} & \multicolumn{2}{|c|}{$\begin{array}{l}\text { SGP participants ( } 65 \\
\text { facilities) }(\%)\end{array}$} & \multicolumn{2}{|c|}{$\begin{array}{l}\text { Non-participants ( } 134 \\
\text { facilities) (\%) }\end{array}$} \\
\hline Facilities in non-attainment counties & \multicolumn{2}{|l|}{14} & \multicolumn{2}{|l|}{18} & \multicolumn{2}{|l|}{12} \\
\hline $\begin{array}{l}\text { Facilities in counties that changed attainment status between } \\
1996 \text { and } 2001\end{array}$ & \multicolumn{2}{|l|}{4} & \multicolumn{2}{|l|}{5} & \multicolumn{2}{|l|}{3} \\
\hline Facilities in affluent neighborhood & \multicolumn{2}{|l|}{18} & \multicolumn{2}{|l|}{22} & \multicolumn{2}{|l|}{16} \\
\hline Members of NAMF & \multicolumn{2}{|l|}{50} & \multicolumn{2}{|l|}{80} & \multicolumn{2}{|l|}{35} \\
\hline Participate in other voluntary programs & \multicolumn{2}{|l|}{9} & \multicolumn{2}{|l|}{12} & \multicolumn{2}{|l|}{7} \\
\hline Publicly traded firms & \multicolumn{2}{|l|}{5} & \multicolumn{2}{|l|}{2} & \multicolumn{2}{|l|}{6} \\
\hline
\end{tabular}

a Reported in natural units (e.g. pounds, dollars) not the units used in the regressions (e.g. logs).

b Reported using total emissions. A similar relationship between groups is found for point emissions.

\subsection{What factors affected a facility's decision to participate in the SGP?}

To identify factors that affected a facility's decision to participate in the SGP, we run a series of probit regressions where the dependent variable, SGP, equals 1 if a facility participated in the SGP and 0 otherwise. There are two basic differences between the four sets of coefficient estimates presented in Table 5. First, we use point source air emissions to define TOTAL TRI RELEASES, MPEM TO TOTAL RELEASES, and PRIOR REDUCTIONS in columns (1) and (2), while we use total air emissions for these variables in columns (3) and (4). Second, we use all 199 observations in columns (1) and (3), while we rely on 166 observations based on facilities that reported to TRI in 1993 (See footnote 11) in columns (2) and (4). Corrections for heteroskedasticity are made using White's estimator of variance.

The results are quite robust across the four specifications for most variables. Generally, the signs of significant coefficients do not change. However, the significance of three variables, NON-ATTAINMENT, MPEM TO TOTAL RELEASES, and a state dummy (CA), vary with sample size: NON-ATTAINMENT and the state dummy are significant only for the full sample, while MPEM TO TOTAL RELEASES is significant only for the restricted sample. We find that the model correctly predicts the participation decision $75 \%$ to $78 \%$ of the time. 
Table 5

Coefficient estimates for the SGP participation equation

\begin{tabular}{|c|c|c|c|c|}
\hline \multirow[t]{2}{*}{ Variables } & \multicolumn{2}{|l|}{ Point air } & \multicolumn{2}{|l|}{ Total air } \\
\hline & $\begin{array}{l}\text { Full sample } \\
\text { (1) }\end{array}$ & $\begin{array}{l}\text { Restricted sample } \\
\text { (2) }\end{array}$ & $\begin{array}{l}\text { Full sample } \\
\text { (3) }\end{array}$ & $\begin{array}{l}\text { Restricted sample } \\
\text { (4) }\end{array}$ \\
\hline TOTAL TRI RELEASES & $\begin{array}{c}0.01 \\
(0.04)\end{array}$ & $\begin{array}{c}0.03 \\
(0.04)\end{array}$ & $\begin{array}{c}-0.02 \\
(0.04)\end{array}$ & $\begin{array}{l}-0.02 \\
(0.04)\end{array}$ \\
\hline PRIOR REDUCTIONS & $\begin{array}{c}0.05 \\
(0.05)\end{array}$ & $\begin{array}{c}0.01 \\
(0.07)\end{array}$ & $\begin{array}{c}0.06 \\
(0.05)\end{array}$ & $\begin{array}{c}0.02 \\
(0.08)\end{array}$ \\
\hline MPEM TO TOTAL RELEASES & $\begin{array}{c}0.47 \\
(0.29)\end{array}$ & $\begin{array}{l}0.66^{* *} \\
(0.32)\end{array}$ & $\begin{array}{c}0.36 \\
(0.26)\end{array}$ & $\begin{array}{c}0.58^{*} \\
(0.31)\end{array}$ \\
\hline PENALTY HISTORY & $\begin{array}{l}-0.06 \\
(0.05)\end{array}$ & $\begin{array}{l}-0.05 \\
(0.05)\end{array}$ & $\begin{array}{l}-0.07 \\
(0.05)\end{array}$ & $\begin{array}{l}-0.05 \\
(0.05)\end{array}$ \\
\hline VIOLATION HISTORY & $\begin{array}{c}0.02 \\
(0.03)\end{array}$ & $\begin{array}{c}0.05 \\
(0.04)\end{array}$ & $\begin{array}{c}0.03 \\
(0.03)\end{array}$ & $\begin{array}{c}0.05 \\
(0.04)\end{array}$ \\
\hline NON-ATTAINMENT & $\begin{array}{c}0.75^{*} \\
(0.39)\end{array}$ & $\begin{array}{c}0.66 \\
(0.41)\end{array}$ & $\begin{array}{c}0.70^{*} \\
(0.37)\end{array}$ & $\begin{array}{c}0.59 \\
(0.39)\end{array}$ \\
\hline STATE REGULATIONS & $\begin{array}{r}1.01^{*} \\
(0.58)\end{array}$ & $\begin{array}{l}1.38^{* *} \\
(0.67)\end{array}$ & $\begin{array}{c}1.04^{*} \\
(0.57)\end{array}$ & $\begin{array}{l}1.39^{* *} \\
(0.63)\end{array}$ \\
\hline PERCENT MINORITY & $\begin{array}{l}-1.28^{* *} \\
(0.63)\end{array}$ & $\begin{array}{l}-1.62^{* *} \\
(0.70)\end{array}$ & $\begin{array}{l}-1.45^{* *} \\
(0.66)\end{array}$ & $\begin{array}{l}-1.87^{* *} \\
(0.71)\end{array}$ \\
\hline POPULATION DENSITY & $\begin{array}{l}0.29^{* *} \\
(0.14)\end{array}$ & $\begin{array}{l}0.42^{* * * *} \\
(0.14)\end{array}$ & $\begin{array}{l}0.28^{* *} \\
(0.13)\end{array}$ & $\begin{array}{l}0.40^{* * *} \\
(0.15)\end{array}$ \\
\hline AFFLUENT & $\begin{array}{c}-0.01 \\
(0.30)\end{array}$ & $\begin{array}{c}-0.18 \\
(0.37)\end{array}$ & $\begin{array}{c}-0.03 \\
(0.30)\end{array}$ & $\begin{array}{l}-0.14 \\
(0.34)\end{array}$ \\
\hline ENV CONTRIBUTIONS & $\begin{array}{l}0.74^{* * *} \\
(0.19)\end{array}$ & $\begin{array}{l}0.74^{* * *} \\
(0.20)\end{array}$ & $\begin{array}{l}0.79^{* * *} \\
(0.19)\end{array}$ & $\begin{array}{l}0.81^{* * *} \\
(0.20)\end{array}$ \\
\hline$N A M F$ & $\begin{array}{l}1.26^{* * * *} \\
(0.25)\end{array}$ & $\begin{array}{l}1.18^{* * *} \\
(0.29)\end{array}$ & $\begin{array}{l}1.20^{* * *} \\
(0.26)\end{array}$ & $\begin{array}{l}1.14^{* * *} \\
(0.30)\end{array}$ \\
\hline OTHER VAS & $\begin{array}{c}0.31 \\
(0.35)\end{array}$ & $\begin{array}{c}0.36 \\
(0.41)\end{array}$ & $\begin{array}{c}0.35 \\
(0.35)\end{array}$ & $\begin{array}{c}0.39 \\
(0.42)\end{array}$ \\
\hline EMPLOYEE SIZE & $\begin{array}{c}0.07 \\
(0.14)\end{array}$ & $\begin{array}{c}-0.08 \\
(0.17)\end{array}$ & $\begin{array}{c}0.12 \\
(0.14)\end{array}$ & $\begin{array}{c}0.04 \\
(0.17)\end{array}$ \\
\hline PUBLIC & $\begin{array}{c}-0.34 \\
(0.47)\end{array}$ & $\begin{array}{c}-0.24 \\
(0.49)\end{array}$ & $\begin{array}{c}-0.25 \\
(0.47)\end{array}$ & $\begin{array}{c}-0.12 \\
(0.46)\end{array}$ \\
\hline$I L$ & $\begin{array}{c}-0.66^{*} \\
(0.35)\end{array}$ & $\begin{array}{c}-0.75^{*} \\
(0.40)\end{array}$ & $\begin{array}{c}-0.64^{*} \\
(0.34)\end{array}$ & $\begin{array}{c}-0.740^{*} \\
(0.40)\end{array}$ \\
\hline$C A$ & $\begin{array}{c}-1.40^{* *} \\
(0.62)\end{array}$ & $\begin{array}{c}-0.82 \\
(0.71)\end{array}$ & $\begin{array}{c}-1.58^{* *} \\
(0.62)\end{array}$ & $\begin{array}{c}-0.99 \\
(0.70)\end{array}$ \\
\hline MI & $\begin{array}{c}0.19 \\
(0.36)\end{array}$ & $\begin{array}{c}0.10 \\
(0.41)\end{array}$ & $\begin{array}{c}0.19 \\
(0.37)\end{array}$ & $\begin{array}{c}0.10 \\
(0.42)\end{array}$ \\
\hline $\mathrm{OH}$ & $\begin{array}{c}-0.55 \\
(0.39)\end{array}$ & $\begin{array}{c}-0.63 \\
(0.41)\end{array}$ & $\begin{array}{c}-0.46 \\
(0.38)\end{array}$ & $\begin{array}{c}-0.49 \\
(0.40)\end{array}$ \\
\hline Constant & $\begin{array}{c}-17.09^{* * *} \\
(3.61)\end{array}$ & $\begin{array}{c}-17.87^{* * *} \\
(3.82)\end{array}$ & $\begin{array}{c}-17.97^{* * *} \\
(3.57)\end{array}$ & $\begin{array}{c}-19.16^{* * *} \\
(4.00)\end{array}$ \\
\hline Log likelihood & -90.44 & -72.80 & -90.62 & -73.15 \\
\hline Percent correctly predicted & 75 & 78 & 76 & 78 \\
\hline Pseudo- $R^{2}$ & 0.28 & 0.30 & 0.28 & 0.30 \\
\hline Observations & 199 & 166 & 199 & 166 \\
\hline
\end{tabular}

Dependent variable: Participation in SGP; equals 1 if facility participates in SGP, equal to 0 otherwise.

The number of stars indicates the level of significance of a coefficient: *indicates it is significant at $10 \%$; **indicates it is significant at $5 \%$; and ${ }^{* * *}$ indicates it is significant at $1 \%$. Robust standard errors are listed in parentheses.

Variables included to account for emissions-related reasons to join the program do not have significant predictive power. PRIOR REDUCTIONS, included to proxy for the ease with which a facility can meet program goals, and TOTAL TRI RELEASES in 1996, included to allow for the possibility that cleaner or more environmentally responsible facilities may be more likely to join, are not significant.

We find that several types of regulatory pressure are relevant to the SGP participation decision. This is consistent with the finding in the existing literature that regulatory pressure encourages real environmental action $[9,20,32,34,35]$. Facilities located in states with more stringent environmental regulations are more likely to join the SGP in all four specifications. The regulatory threat variable, MPEM TO TOTAL RELEASES, is positive and significant for the restricted sample specifications. This result lends some support to anecdotal evidence that the MP\&M rule played an important role in the SGP, with the proportion of a facility's emissions stemming from chemicals potentially subject to the MP\&M rule positively affecting the likelihood of joining the SGP. Facilities that are located in a county out of attainment with federal air regulations also are more likely to join the SGP, but this result is only significant in the full sample. Finally, larger penalties 
Table 6

Marginal effects for variables significantly affecting SGP participation

\begin{tabular}{|c|c|c|c|c|}
\hline \multirow[t]{2}{*}{ Variables } & \multicolumn{2}{|l|}{ Point air } & \multicolumn{2}{|l|}{ Total air } \\
\hline & $\begin{array}{l}\text { Full sample } \\
\text { (1) }\end{array}$ & $\begin{array}{l}\text { Restricted sample } \\
\text { (2) }\end{array}$ & $\begin{array}{l}\text { Full sample } \\
\text { (3) }\end{array}$ & $\begin{array}{l}\text { Restricted sample } \\
\text { (4) }\end{array}$ \\
\hline MPEM TO TOTAL RELEASES & $\begin{array}{c}0.14 \\
(0.09)\end{array}$ & $\begin{array}{l}0.20^{* *} \\
(0.09)\end{array}$ & $\begin{array}{c}0.11 \\
(0.08)\end{array}$ & $\begin{array}{c}0.17^{*} \\
(0.09)\end{array}$ \\
\hline NON-ATTAINMENT & $\begin{array}{c}0.27^{*} \\
(0.15)\end{array}$ & $\begin{array}{c}0.23 \\
(0.15)\end{array}$ & $\begin{array}{c}0.24^{*} \\
(0.14)\end{array}$ & $\begin{array}{c}0.20 \\
(0.14)\end{array}$ \\
\hline STATE REGULATIONS & $\begin{array}{r}0.31^{*} \\
(0.18)\end{array}$ & $\begin{array}{c}0.42^{* * *} \\
(0.20)\end{array}$ & $\begin{array}{c}0.32^{*} \\
(0.18)\end{array}$ & $\begin{array}{l}0.41^{* *} \\
0.19\end{array}$ \\
\hline PERCENT MINORITY & $\begin{array}{l}-0.40^{* *} \\
(0.20)\end{array}$ & $\begin{array}{l}-0.49^{* *} \\
(0.21)\end{array}$ & $\begin{array}{l}-0.45^{* *} \\
(0.20)\end{array}$ & $\begin{array}{l}-0.56^{* *} \\
(0.21)\end{array}$ \\
\hline POPULATION DENSITY & $\begin{array}{l}0.09^{* *} \\
(0.04)\end{array}$ & $\begin{array}{l}0.13^{* * *} \\
(0.04)\end{array}$ & $\begin{array}{c}0.09^{* *} \\
(0.04)\end{array}$ & $\begin{array}{l}0.12^{* * *} \\
(0.04)\end{array}$ \\
\hline ENV CONTRIBUTIONS & $\begin{array}{l}0.23^{* * *} \\
(0.06)\end{array}$ & $\begin{array}{l}0.23^{* * *} \\
(0.06)\end{array}$ & $\begin{array}{l}0.24^{* * *} \\
(0.05)\end{array}$ & $\begin{array}{l}0.24^{* * *} \\
(0.06)\end{array}$ \\
\hline NAMF & $\begin{array}{l}0.38^{* * *} \\
(0.07)\end{array}$ & $\begin{array}{l}0.35^{* * *} \\
(0.08)\end{array}$ & $\begin{array}{l}0.36^{* * *} \\
(0.07)\end{array}$ & $\begin{array}{l}0.33^{* * *} \\
(0.08)\end{array}$ \\
\hline$I L$ & $\begin{array}{c}-0.18^{*} \\
(0.08)\end{array}$ & $\begin{array}{r}-0.19^{*} \\
(0.08)\end{array}$ & $\begin{array}{r}-0.17^{*} \\
(0.07)\end{array}$ & $\begin{array}{c}-0.17^{*} \\
(0.08)\end{array}$ \\
\hline$C A$ & $\begin{array}{l}-0.26^{* *} \\
(0.06)\end{array}$ & $\begin{array}{c}-0.18 \\
(0.10)\end{array}$ & $\begin{array}{c}-0.26^{* *} \\
(0.05)\end{array}$ & $\begin{array}{c}-0.20 \\
(0.08)\end{array}$ \\
\hline
\end{tabular}

or a greater number of violations do not appear to affect a facility's SGP decision. This may be because facilities do not view voluntary programs as having an impact on the amount of regulatory scrutiny they face from the EPA.

Two of the variables included to measure community pressure, PERCENT MINORITY and POPULATION DENSITY, are significant. A higher share of minorities in the neighborhood reduces the likelihood that the facility joins the SGP. Facilities in denser neighborhoods are more likely to join the SGP. To the extent that these variables proxy for the degree of community pressure the facility faces, they adhere to hypotheses in the literature [17]. A facility that wants to minimize potential compensation to the community for environmental damages is more likely to join a voluntary program in areas where there are higher levels of collective action and more people to potentially compensate. The variable AFFLUENT is not significant, but as a dummy variable this variable may not suitably capture differences in income levels. ENV CONTRIBUTIONS is positive and significant. The more dues and contributions received by state environmental groups, the more likely a facility in that state joins the SGP. The California and Illinois dummies are generally negative and significant: a facility located in a state with a large number of metal-finishing facilities is less likely to join the SGP. This may indicate that there are few spillovers across facilities within a state with regard to the voluntary program.

Of the firm and facility characteristics included in the regressions, only NAMF is significant. Facilities that belong to the trade association are more likely to join the SGP. This finding adheres to expectations, since NAMF was actively involved in the creation of the voluntary program, advertised the SGP widely to its members, and encouraged them to join. ${ }^{15}$

Table 6 reports the marginal effects of a change in each of the significant variables upon the probability of joining the SGP. For the purpose of discussion, we refer to the marginal effects for point air emissions, listed in column 1 . The largest marginal effect is associated with NAMF members: they are 38\% more likely to join the SGP. Several other dummy variables also have large effects: facilities located in non-attainment counties are $27 \%$ more likely to join the SGP, and those in California and Illinois are $26 \%$ and $18 \%$ less likely to join the SGP, respectively. Of the continuous variables, STATE REGULATIONS, PERCENT MINORITY, and ENV CONTRIBUTIONS have the largest effects. For instance, a $1 \%$ increase in a state's Levinson index increases the probability of facilities in that state joining by $0.31 \%$ while an increase of $1 \%$ in the proportion of minorities surrounding a facility decreases the likelihood of joining the SGP by $0.40 \%$.

\subsection{Did the SGP and MPEM regulatory threat affect facility air emissions?}

We next examine the results for the emissions change regression, presented in Table 7. The dependent variable is the difference in logs of average air emissions from 2002-2003 to 1995-1996. Care should be taken in interpreting the coefficient estimates: if a facility increases emissions over time, then the dependent variable is positive; if a facility reduces emissions over time then the dependent variable is negative. We use point source air emissions to define the dependent variable as well as CHANGE IN MPEM TO TOTAL RELEASES and TOTAL TRI RELEASES in columns (1) and (2). We use total air emissions to define these variables in columns (3) and (4). All 199 observations are used in columns (1) and (3), while we

\footnotetext{
${ }^{15}$ In an alternate specification, we also examine the possibility that larger facilities are more like to participate in the SGP when located in a state with higher environmental contributions. When this interaction variable is included, EMPLOYEE SIZE is significant. However, ENV CONTRIBUTIONS is no longer significant, the interaction term is not significant, and the marginal effects and pseudo- $R$ squared are unaffected.
} 
Table 7

Coefficient estimates for the change in emissions equation

\begin{tabular}{|c|c|c|c|c|}
\hline \multirow[t]{2}{*}{ Variables } & \multicolumn{2}{|l|}{ Point air } & \multicolumn{2}{|l|}{ Total air } \\
\hline & $\begin{array}{l}\text { Full sample } \\
\text { (1) }\end{array}$ & $\begin{array}{l}\text { Restricted sample } \\
\text { (2) }\end{array}$ & $\begin{array}{l}\text { Full sample } \\
\text { (3) }\end{array}$ & $\begin{array}{l}\text { Restricted sample } \\
\text { (4) }\end{array}$ \\
\hline Probability of joining SGP & $\begin{array}{l}-1.54 \\
(0.99)\end{array}$ & $\begin{array}{l}-1.31 \\
(0.85)\end{array}$ & $\begin{array}{l}-1.34 \\
(0.90)\end{array}$ & $\begin{array}{l}-0.59 \\
(0.86)\end{array}$ \\
\hline TOTAL TRI RELEASES & $\begin{array}{l}-0.19^{* * *} \\
(0.05)\end{array}$ & $\begin{array}{l}-0.18^{* * *} \\
(0.05)\end{array}$ & $\begin{array}{l}-0.30^{* * *} \\
(0.06)\end{array}$ & $\begin{array}{l}-0.27^{* * *} \\
(0.06)\end{array}$ \\
\hline CHANGE IN MPE'M TO TOTAL RELEASES & $\begin{array}{l}3.19^{* * *} \\
(0.45)\end{array}$ & $\begin{array}{l}3.43^{* * *} \\
(0.49)\end{array}$ & $\begin{array}{l}3.12^{* * *} \\
(0.50)\end{array}$ & $\begin{array}{l}3.37^{* * *} \\
(0.50)\end{array}$ \\
\hline TOTAL PENALTIES & $\begin{array}{c}0.02 \\
(0.04)\end{array}$ & $\begin{array}{c}0.05 \\
(0.04)\end{array}$ & $\begin{array}{c}0.03 \\
(0.04)\end{array}$ & $\begin{array}{c}0.03 \\
(0.05)\end{array}$ \\
\hline TOTAL INSPECTIONS & $\begin{array}{c}-0.16 \\
(0.12)\end{array}$ & $\begin{array}{c}-0.24^{*} \\
(0.13)\end{array}$ & $\begin{array}{r}-0.26^{*} \\
(0.14)\end{array}$ & $\begin{array}{c}-0.31^{* *} \\
(0.14)\end{array}$ \\
\hline CHANGE IN NON-ATTAINMENT & $\begin{array}{r}-1.42^{*} \\
(0.73)\end{array}$ & $\begin{array}{l}-1.76^{* *} \\
(0.88)\end{array}$ & $\begin{array}{r}-0.72 \\
(1.10)\end{array}$ & $\begin{array}{c}-0.65 \\
(1.36)\end{array}$ \\
\hline PERCENT MINORITY & $\begin{array}{l}-0.05 \\
(0.82)\end{array}$ & $\begin{array}{l}-0.12 \\
(0.76)\end{array}$ & $\begin{array}{c}0.22 \\
(0.84)\end{array}$ & $\begin{array}{c}0.50 \\
(0.74)\end{array}$ \\
\hline POPULATION DENSITY & $\begin{array}{c}-0.09 \\
(0.19)\end{array}$ & $\begin{array}{c}-0.02 \\
(0.15)\end{array}$ & $\begin{array}{c}-0.07 \\
(0.17)\end{array}$ & $\begin{array}{c}-0.12 \\
(0.13)\end{array}$ \\
\hline CHANGE IN ENV CONTRIBUTIONS & $\begin{array}{c}0.10 \\
(0.39)\end{array}$ & $\begin{array}{c}0.09 \\
(0.44)\end{array}$ & $\begin{array}{c}0.09 \\
(0.42)\end{array}$ & $\begin{array}{c}0.24 \\
(0.50)\end{array}$ \\
\hline$N A M F$ & $\begin{array}{r}0.95^{*} \\
(0.52)\end{array}$ & $\begin{array}{c}0.89 * * \\
(0.44)\end{array}$ & $\begin{array}{c}0.79 * \\
(0.45)\end{array}$ & $\begin{array}{c}0.62 \\
(0.40)\end{array}$ \\
\hline OTHER VAs & $\begin{array}{c}0.25 \\
(0.40)\end{array}$ & $\begin{array}{c}0.49 \\
(0.32)\end{array}$ & $\begin{array}{c}0.16 \\
(0.44)\end{array}$ & $\begin{array}{c}0.26 \\
(0.30)\end{array}$ \\
\hline EMPLOYEE SIZE & $\begin{array}{c}0.44^{* *} \\
(0.17)\end{array}$ & $\begin{array}{c}0.35^{* *} \\
(0.17)\end{array}$ & $\begin{array}{c}0.36^{* *} \\
(0.18)\end{array}$ & $\begin{array}{c}0.28^{*} \\
(0.16)\end{array}$ \\
\hline PUBLIC & $\begin{array}{r}-1.46^{*} \\
(0.77)\end{array}$ & $\begin{array}{r}-1.38^{*} \\
(0.76)\end{array}$ & $\begin{array}{c}-0.68 \\
(0.54)\end{array}$ & $\begin{array}{c}-0.65 \\
(0.51)\end{array}$ \\
\hline IL & $\begin{array}{c}-0.70 \\
(0.60)\end{array}$ & $\begin{array}{c}-0.86 \\
(0.57)\end{array}$ & $\begin{array}{c}-0.64 \\
(0.60)\end{array}$ & $\begin{array}{c}-0.38 \\
(0.59)\end{array}$ \\
\hline$C A$ & $\begin{array}{r}-1.14^{*} \\
(0.63)\end{array}$ & $\begin{array}{c}-1.17 \\
(0.89)\end{array}$ & $\begin{array}{c}-1.96^{* * *} \\
(0.74)\end{array}$ & $\begin{array}{c}-1.44 \\
(1.01)\end{array}$ \\
\hline MI & $\begin{array}{c}-0.11 \\
(0.44)\end{array}$ & $\begin{array}{c}-0.21 \\
(0.53)\end{array}$ & $\begin{array}{c}-0.46 \\
(0.43)\end{array}$ & $\begin{array}{c}-0.24 \\
(0.48)\end{array}$ \\
\hline $\mathrm{OH}$ & $\begin{array}{c}-0.61 \\
(0.50)\end{array}$ & $\begin{array}{r}-0.80^{*} \\
(0.42)\end{array}$ & $\begin{array}{c}-0.75 \\
(0.50)\end{array}$ & $\begin{array}{c}-0.35 \\
(0.42)\end{array}$ \\
\hline Constant & $\begin{array}{c}-0.25 \\
(1.54)\end{array}$ & $\begin{array}{c}-0.42 \\
(1.21)\end{array}$ & $\begin{array}{r}-1.02 \\
(1.54)\end{array}$ & $\begin{array}{c}1.24 \\
(1.19)\end{array}$ \\
\hline$R$-squared & 0.41 & 0.44 & 0.41 & 0.43 \\
\hline Observations & 199 & 166 & 199 & 166 \\
\hline
\end{tabular}

Dependent variable: log average air emissions in 2002-2003 minus log average air emissions in 1995-1996.

Note that *indicates a coefficient is significant at $10 \%$; **indicates it is significant at $5 \%$; and ${ }^{* * *}$ indicates it is significant at $1 \%$. Robust standard errors are listed in parentheses.

restrict the sample to 166 observations based on facilities that reported to TRI in 1993 (see footnote 11) in columns (2) and (4). We correct for heteroskedasticity in all specifications using White's estimator of variance.

Before discussing the results, recall that we include the predicted probability of joining the SGP as an independent variable in the regression. Previous literature $[19,23,40]$ takes a similar approach under the assumption that facilities that are most likely to join may also be most likely to reduce emissions. If this is the case, including SGP participation directly in the emissions regression would bias the results. A common solution has been to regress the participation decision on a set of independent variables and then use the predicted probability of participation as an instrument in the emission equation, rather than to explicitly test for the existence of such bias in the participation decision. Employing such a test here, we reject the null hypothesis that OLS yields consistent estimates for three of the four specifications. ${ }^{16}$ This result suggests that the use of the predicted probability of joining the SGP probably is warranted when evaluating facility emissions behavior.

\footnotetext{
${ }^{16}$ Our test for endogeneity is complicated because participation is modeled using a probit. The standard approach is to use the Durbin-Wu-Hausman test: the variable suspected to be endogeneous is regressed on a set of instruments, and then the residuals from this regression and the suspected variable are included in the subsequent regression. If the coefficient on the residuals significantly differs from zero, then the suspected variable is endogenous and the instrumental variable approach is warranted. However, this test is commonly conducted when the variable in question is linearly modeled. If we employ OLS for our participation decision and test for endogenity, we reject the null hypothesis of a zero coefficient in three of four cases. If we use a probit for the participation decision, the interpretation of errors is more difficult. Davidson and MacKinnon [7] show that including the predicted variables from a modeled instrument rather than the residuals and testing for significance produces an equivalent result. Using the predicted values of our probit to test for endogeneity, we reject the null hypothesis for point source emissions (and thus, suspect endogenity), but fail to reject it for total air emissions.
} 
We begin by discussing whether the probability of joining the SGP had an effect on the change in average emissions prior to the program in 1995-1996, relative to just after its completion in 2002-2003. The coefficient on the probability of joining the SGP is negative in all four cases: facilities with a high probability of joining the SGP reduce emissions by more than facilities with a low probability of joining. While this result appears to support the effectiveness of the SGP, it is not significant for any specification. Alternate specifications of the model show that this conclusion is relatively robust for the overall study period. This result lends itself to the hypothesis in the literature that facilities often may join voluntary programs with good intentions but make few real changes in behavior as a direct result of joining the program. We know from the summary statistics that SGP facilities, on average, emit less initially than non-SGP facilities. This may mean that while relatively clean facilities derived some benefit from joining the SGP, there was not sufficient incentive for these facilities to further reduce emissions.

The regulatory threat variable, CHANGE IN MPEM TO TOTAL RELEASES, is consistently significant and positively related to emission changes for all specifications. This implies that the proposed MP\&M regulation had a discernible effect on behavior: facilities that reduced emissions of MP\&M chemicals relative to total releases made more progress in reducing overall air emissions over this time period. Coupled with the insignificant result on the predicted probability of joining the SGP, this result provides evidence that the voluntary program alone did not effectively replace the traditional policy tool, the threat of which appears to be a large motivating factor for reducing emissions. In a set of regressions not presented here, we included an interaction term between the predicted probability of joining SGP and the MP\&M variable. ${ }^{17}$ It was not significant in any specification. Thus, the two variables can be interpreted as measuring the separate effect of each policy variable on emissions. However, it is worth noting that our regulatory threat variable only captures an individual facility's potential vulnerability to the cost of future regulation. Overall industry performance, relevant for affecting the likelihood of regulation and its relative stringency, is not captured by this variable.

Only one other variable associated with regulatory pressure is significant across most specifications: TOTAL INSPECTIONS. The number of inspections a facility faced in 1995 and 1996 is negatively correlated with emission changes. This result is intuitive: facilities that historically have been inspected more frequently by the EPA reduce emissions by more than facilities that face less oversight. Change in NON-ATTAINMENT status also has a negative coefficient, but it is significant only for point source air emissions. This variable indicates that facilities in counties that went into attainment reduced point air emissions more than facilities in counties where attainment status remained unchanged.

The variable TOTAL TRI RELEASES is negatively correlated with emission changes over the study period for all specifications. In other words, the dirtier the facility in 1996, the more progress it made in reducing emissions over the next 7 years. This result makes sense if we consider that dirtier facilities may be able to invest relatively little initially to make large reductions in emissions; cleaner facilities may have already found the "low-hanging fruit," the simplest and least costly reductions and therefore incur higher costs to reduce emissions further.

Variables included in the regressions to capture community or environmental pressure, PERCENT MINORITY, POPULATION DENSITY, and CHANGE IN ENV CONTRIBUTIONS, are not significant. While these variables may influence a facility's decision of whether to join the SGP, they do not appear to influence decisions of how much to reduce emissions.

Of the firm and facility characteristics included, EMPLOYEE SIZE is positive and significant for all specifications: larger facilities reduce emissions less than smaller facilities. ${ }^{18}$ Membership in the industry trade association, NAMF, which had a strong influence on a facility's decision to join the SGP, is significant for three of four specifications. However, it is also positive, meaning that NAMF members made fewer reductions than non-members. In an alternate specification not presented here, we examine the possibility that facilities belonging to both NAMF and the SGP respond differently than NAMF members that did not join the SGP. That variable was never significant nor did it affect the sign or significance of NAMF. Finally, if a facility is PUBLIC, we find that it reduced emissions more than privately held facilities. This result holds true for all specifications but is significant only for point air emissions.

\subsection{Did the SGP and regulatory threat have a different effect on emissions over time?}

As previously noted, the nature of the regulatory threat faced by metal finishers varied over time. The MP\&M regulation was first proposed in 1995 and was re-proposed in 2001 with more stringent limits. Thus, we have reason to expect that facilities reduced emissions in response to the initial regulatory threat as well as to an increase in its relative stringency.

There are also several reasons to expect the effect of the SGP on emissions varied over time. Lyon and Maxwell [30] suggest that a voluntary program may have a differential impact on emissions over time because it increases the diffusion of cost-effective abatement techniques. This hypothesis suggests that SGP participants may initially reduce emissions by more than non-participants due to information gained via the voluntary program. However as information diffuses nonparticipants also utilize these techniques, which would then reduce the discrepancy in emission changes across the two groups. An alternative hypothesis to that proposed by Lyon and Maxwell suggests an explicit interaction between the two

\footnotetext{
${ }^{17}$ We also interact the variables CHANGE IN ENV CONTRIBUTIONS and EMPLOYEE SIZE. The interaction term is not significant for any of the specifications.

18 More relevant than employee size at a given point in time is the change in the number of employees or sales over time. However, we do not have access to such data. Since we are unable to control for production changes, we are implicitly assuming that changes in output, if any, are independent of SGP participation.
} 
Table 8

Coefficient estimates for the change in emissions equation by time period

\begin{tabular}{|c|c|c|c|c|c|c|}
\hline \multirow[t]{2}{*}{ Variables } & \multicolumn{2}{|c|}{$\begin{array}{l}\text { Entire time period 1995/1996-2002/ } \\
2003\end{array}$} & \multicolumn{2}{|c|}{$\begin{array}{l}\text { Early time period } 1995 / 1996-1999 / \\
2000\end{array}$} & \multicolumn{2}{|c|}{$\begin{array}{l}\text { Late time period } 1999 / 2000-2002 / \\
2003\end{array}$} \\
\hline & $\begin{array}{l}\text { Total air } \\
(1)\end{array}$ & $\begin{array}{l}\text { Point air } \\
(2)\end{array}$ & $\begin{array}{l}\text { Total air } \\
\text { (3) }\end{array}$ & $\begin{array}{l}\text { Point air } \\
\text { (4) }\end{array}$ & $\begin{array}{l}\text { Total air } \\
\text { (5) }\end{array}$ & $\begin{array}{l}\text { Point air } \\
\text { (6) }\end{array}$ \\
\hline Probability of joining SGP & $\begin{array}{l}-1.34 \\
(0.90)\end{array}$ & $\begin{array}{l}-1.54 \\
(0.99)\end{array}$ & $\begin{array}{l}1.93^{* *} \\
(0.87)\end{array}$ & $\begin{array}{c}0.92 \\
(0.93)\end{array}$ & $\begin{array}{l}-2.97^{* * *} \\
(0.83)\end{array}$ & $\begin{array}{r}-1.70^{*} \\
(0.99)\end{array}$ \\
\hline TOTAL TRI RELEASES & $\begin{array}{l}-0.30^{* * *} \\
(0.06)\end{array}$ & $\begin{array}{l}-0.19^{* * *} \\
(0.05)\end{array}$ & $\begin{array}{l}-0.22^{* * *} \\
(0.05)\end{array}$ & $\begin{array}{l}-0.20^{* * *} \\
(0.05)\end{array}$ & $\begin{array}{l}-0.22^{* * *} \\
(0.05)\end{array}$ & $\begin{array}{l}-0.16^{* * *} \\
(0.05)\end{array}$ \\
\hline CHANGE IN MPEM TO TOTAL RELEASES & $\begin{array}{l}3.12^{* * *} \\
(0.50)\end{array}$ & $\begin{array}{l}3.19^{* * *} \\
(0.45)\end{array}$ & $\begin{array}{l}4.11^{* * *} \\
(0.48)\end{array}$ & $\begin{array}{l}4.02^{* * *} \\
(0.48)\end{array}$ & $\begin{array}{l}2.01^{* * *} \\
(0.64)\end{array}$ & $\begin{array}{l}2.53^{* * *} \\
(0.49)\end{array}$ \\
\hline TOTAL PENALTIES & $\begin{array}{c}0.03 \\
(0.04)\end{array}$ & $\begin{array}{c}0.02 \\
(0.04)\end{array}$ & $\begin{array}{c}0.04 \\
(0.04)\end{array}$ & $\begin{array}{c}0.06^{*} \\
(0.04)\end{array}$ & $\begin{array}{c}0.05 \\
(0.03)\end{array}$ & $\begin{array}{c}0.02 \\
(0.03)\end{array}$ \\
\hline TOTAL INSPECTIONS & $\begin{array}{c}-0.26^{*} \\
(0.14)\end{array}$ & $\begin{array}{c}-0.16 \\
(0.12)\end{array}$ & $\begin{array}{c}-0.02 \\
(0.12)\end{array}$ & $\begin{array}{c}0.15 \\
(0.11)\end{array}$ & $\begin{array}{c}-0.20^{* *} \\
(0.10)\end{array}$ & $\begin{array}{c}-0.11^{*} \\
(0.06)\end{array}$ \\
\hline CHANGE IN NON-ATTAINMENT & $\begin{array}{c}-0.72 \\
(1.10)\end{array}$ & $\begin{array}{r}-1.42^{*} \\
(0.73)\end{array}$ & $\begin{array}{c}-1.30^{* *} \\
(0.51)\end{array}$ & $\begin{array}{r}-1.02^{*} \\
(0.57)\end{array}$ & $\begin{array}{c}-1.49^{* *} \\
(0.72)\end{array}$ & $\begin{array}{c}-1.22 \\
(0.81)\end{array}$ \\
\hline PERCENT MINORITY & $\begin{array}{c}0.22 \\
(0.84)\end{array}$ & $\begin{array}{c}-0.05 \\
(0.82)\end{array}$ & $\begin{array}{c}1.21 \\
(0.83)\end{array}$ & $\begin{array}{r}1.32 * \\
(0.72)\end{array}$ & $\begin{array}{c}-0.94 \\
(0.60)\end{array}$ & $\begin{array}{c}-0.92 \\
(0.67)\end{array}$ \\
\hline POPULATION DENSITY & $\begin{array}{c}-0.07 \\
(0.17)\end{array}$ & $\begin{array}{c}-0.09 \\
(0.19)\end{array}$ & $\begin{array}{c}-0.20 \\
(0.16)\end{array}$ & $\begin{array}{c}-0.24 \\
(0.17)\end{array}$ & $\begin{array}{c}0.15 \\
(0.12)\end{array}$ & $\begin{array}{c}0.06 \\
(0.11)\end{array}$ \\
\hline CHANGE IN ENV CONTRIBUTIONS & $\begin{array}{c}0.09 \\
(0.42)\end{array}$ & $\begin{array}{c}0.10 \\
(0.39)\end{array}$ & $\begin{array}{c}0.34 \\
(0.62)\end{array}$ & $\begin{array}{c}0.57 \\
(0.51)\end{array}$ & $\begin{array}{c}0.37 \\
(0.31)\end{array}$ & $\begin{array}{c}0.24 \\
(0.32)\end{array}$ \\
\hline NAMF & $\begin{array}{c}0.79^{*} \\
(0.45)\end{array}$ & $\begin{array}{r}0.95^{*} \\
(0.52)\end{array}$ & $\begin{array}{c}-0.67 \\
(0.45)\end{array}$ & $\begin{array}{c}-0.38 \\
(0.48)\end{array}$ & $\begin{array}{l}1.46^{* * * *} \\
(0.45)\end{array}$ & $\begin{array}{r}1.02^{*} \\
(0.53)\end{array}$ \\
\hline OTHER VAS & $\begin{array}{c}0.16 \\
(0.44)\end{array}$ & $\begin{array}{c}0.25 \\
(0.40)\end{array}$ & $\begin{array}{c}0.25 \\
(0.32)\end{array}$ & $\begin{array}{c}0.25 \\
(0.30)\end{array}$ & $\begin{array}{c}0.24 \\
(0.31)\end{array}$ & $\begin{array}{c}0.26 \\
(0.32)\end{array}$ \\
\hline EMPLOYEE SIZE & $\begin{array}{c}0.36^{* *} \\
(0.18)\end{array}$ & $\begin{array}{c}0.44^{* *} \\
(0.17)\end{array}$ & $\begin{array}{c}0.08 \\
(0.17)\end{array}$ & $\begin{array}{c}0.28 \\
(0.19)\end{array}$ & $\begin{array}{l}0.48^{* * *} \\
(0.17)\end{array}$ & $\begin{array}{c}0.45^{* *} \\
(0.18)\end{array}$ \\
\hline PUBLIC & $\begin{array}{c}-0.68 \\
(0.54)\end{array}$ & $\begin{array}{r}-1.46^{*} \\
(0.77)\end{array}$ & $\begin{array}{c}-0.96 \\
(0.78)\end{array}$ & $\begin{array}{c}-1.37 \\
(0.83)\end{array}$ & $\begin{array}{c}0.09 \\
(0.63)\end{array}$ & $\begin{array}{c}-0.06 \\
(0.70)\end{array}$ \\
\hline IL & $\begin{array}{c}-0.64 \\
(0.60)\end{array}$ & $\begin{array}{c}-0.70 \\
(0.60)\end{array}$ & $\begin{array}{c}0.33 \\
(0.39)\end{array}$ & $\begin{array}{c}-0.13 \\
(0.46)\end{array}$ & $\begin{array}{c}-0.53 \\
(0.40)\end{array}$ & $\begin{array}{c}-0.17 \\
(0.51)\end{array}$ \\
\hline$C A$ & $\begin{array}{c}-1.96^{* * *} \\
(0.74)\end{array}$ & $\begin{array}{r}-1.14^{*} \\
(0.63)\end{array}$ & $\begin{array}{c}-2.07^{* * *} \\
(0.74)\end{array}$ & $\begin{array}{c}-1.16^{* *} \\
(0.59)\end{array}$ & $\begin{array}{c}-0.46 \\
(0.63)\end{array}$ & $\begin{array}{c}-0.17 \\
(0.40)\end{array}$ \\
\hline MI & $\begin{array}{c}-0.46 \\
(0.43)\end{array}$ & $\begin{array}{c}-0.11 \\
(0.44)\end{array}$ & $\begin{array}{r}-0.48 \\
(0.43)\end{array}$ & $\begin{array}{c}0.15 \\
(0.41)\end{array}$ & $\begin{array}{r}-0.35 \\
(0.34)\end{array}$ & $\begin{array}{r}-0.43 \\
(0.31)\end{array}$ \\
\hline $\mathrm{OH}$ & $\begin{array}{c}-0.75 \\
(0.50)\end{array}$ & $\begin{array}{c}-0.61 \\
(0.50)\end{array}$ & $\begin{array}{c}0.76^{* *} \\
(0.38)\end{array}$ & $\begin{array}{c}0.71^{*} \\
(0.41)\end{array}$ & $\begin{array}{c}-1.66^{* * *} \\
(0.56)\end{array}$ & $\begin{array}{c}-1.42^{* *} \\
(0.62)\end{array}$ \\
\hline Constant & $\begin{array}{c}1.02 \\
(1.54)\end{array}$ & $\begin{array}{c}-0.25 \\
(1.54)\end{array}$ & $\begin{array}{c}1.49 \\
(1.45)\end{array}$ & $\begin{array}{c}0.16 \\
(1.42)\end{array}$ & $\begin{array}{c}-0.86 \\
(1.03)\end{array}$ & $\begin{array}{c}-1.03 \\
(1.01)\end{array}$ \\
\hline$R$-squared & 0.41 & 0.41 & 0.41 & 0.45 & 0.32 & 0.27 \\
\hline Observations & 199 & 199 & 199 & 199 & 199 & 199 \\
\hline
\end{tabular}

Note that CHANGE IN TOTAL TO MPEM RELEASES, CHANGE IN NON-ATTAINMENT, and CHANGE IN ENV CONTRIBUTIONS have been adjusted to the relevant time period, though we only have data through 2002 on non-attainment status and through 2001 for state environmental contributions. For levels of TOTAL TRI RELEASES, TOTAL INSPECTIONS, and TOTAL PENALTIES, we have redefined them in the later time period as follows: TOTAL TRI RELEASES uses 1999 data; TOTAL INSPECTIONS and TOTAL PENALTIES use 1999 and 2000 data.

Note that *indicates a coefficient is significant at $10 \%$; ${ }^{* *}$ indicates it is significant at $5 \%$; and ${ }^{* * *}$ indicates it is significant at $1 \%$. Robust standard errors are listed in parentheses.

policy levers - that participants may use the SGP as a signal to regulators of environmental responsibility to reduce the likelihood of future or stricter regulations $[9,29,32,35]$. How strongly this signal is conveyed to regulators may depend on the immediacy and severity of the threat faced by the industry as well as how costly it may be to the individual facility and/ or firm. When the threat of regulation is low, participation by some sub-group of the industry in the voluntary program may be sufficient as a signal. As the threat of regulation grows, however, the industry may face increased pressure to show regulators that the voluntary program provides real emissions reductions and that the proposed regulation is therefore unnecessary. With a strong regulatory threat, individual facilities also have an incentive to reduce emissions to lower their vulnerability to (and costs from) future regulation. This hypothesis suggests that, in spite of incentives for some firms to free-ride, participants will reduce emissions more when the regulatory threat is more severe.

We split the sample into two time periods to examine whether the impact of the MP\&M regulatory threat and the SGP vary across time: We use average emissions from 1999 to 2000 as the halfway point. The initial time period includes only the first few years of the program and is characterized by a lower threat of regulation and possibly limited information diffusion to non-participants of the SGP. The subsequent time period includes emission changes at the end of the SGP (relative to the early years of the program) and is characterized by a higher threat of regulation and possibly broader information dissemination to non-participants. The results for the emissions change regression over the two time periods 
are presented in Table 8 . We present only the results for the full sample here. ${ }^{19}$ Independent variables that change over time have been adjusted to reflect the appropriate time period (see Table 8 ).

Unlike results for the entire study period, the effect of the predicted probability of joining the SGP on emission changes is consistently significant in the later time period and significant in one of two specifications for the earlier time period. These results suggest that the SGP had an effect on participant behavior and that it varied across time periods. SGP participants initially reduce emissions by less than non-participants relative to pre-program emissions. However, in the later time period, SGP participants reduce emissions by more than non-participants.

The facility-specific measure of the regulatory threat, CHANGE IN MPEM TO TOTAL RELEASES, continues to be consistently significant and positively related to emission changes. This means that facilities (i.e., participants and nonparticipants) react to the initial regulatory threat by reducing emissions and then react again to an increase in its relative stringency by reducing emissions further. ${ }^{20}$ Based on this evidence, it is possible to make the case that the threat of regulation induced metal finishers, regardless of participation in the SGP, to decrease emissions in an attempt to reduce their vulnerability to future regulation. Evidence also indicates that CHANGE IN NON-ATTAINMENT is related to emission reductions for both the early and later time periods. However, a number of variables that are significant in the original regressions for the entire study period only appear to be relevant in the later time period (i.e., TOTAL INSPECTIONS, EMPLOYEE SIZE, and NAMF). This may be due in part to the limited ability to change emissions in the short term. Signs are consistent with those for the entire study period.

An initial examination of these results seems to indicate little support for the hypothesis that initial access to better information through the SGP results in greater reductions by participants in the first few years, but that differences between participants and non-participants dissipate over time as information spreads. There is a possible explanation for the observed behavior, however, that may still be consistent with information dissemination over time. Recall that SGP participants tend to be relatively cleaner facilities. It is possible that SGP participants were already well informed with regard to possible abatement opportunities and-in fact-made use of those opportunities prior to joining the program, so that the SGP did not have a large effect on behavior initially. Over time, these facilities may have benefited from access to new information via the SGP (and increased flexibility) that allowed them to take advantage of additional abatement opportunities. It is still possible that such information is then subsequently disseminated to non-participants.

The finding of a differential impact of the predicted probability of joining the SGP on emission behavior over time seems broadly consistent with the hypothesis that participants changed emissions due to a change in the regulatory threat faced by the industry as a whole. While free-riding may complicate the ability of the industry to clearly communicate a strong signal to regulators via the voluntary program, the regulatory threat does contribute significantly to explaining why a subgroup of the metal-finishing industry joined the SGP. We also find that these participants reduced emissions differentially relative to non-participants over the two time periods. This points to the possibility that, as a group, participants may have attempted to use the SGP as a way to forestall future regulation.

It is worth noting, however, that the impact of a participants' individual vulnerability to future regulation (measured by the MP\&M variable) on emissions appears to be independent from the predicted probability of joining the SGP. When an interaction term is included in the regressions (not presented here), it is not significant for any specification. Thus, the coefficient on the SGP variable only measures the effect of joining the program, absent the effect of the regulatory threat on an individual facility's vulnerability to potential regulation (and vice versa).

\section{Conclusion}

In this paper, we examine the impact of two policy levers, a voluntary program and the threat of regulation, on the emissions behavior of facilities in the metal-finishing industry. We first use a probit model to examine factors that contribute to a facility's decision of whether to participate in the SGP. Finding evidence of endogeneity, we use the results of the probit equation to calculate the predicted probability of joining the SGP and include this variable on the right-hand side of the emissions reductions equation, along with measures of the regulatory threat and other relevant measures of external pressure. Factors related to several forms of external pressure such as community characteristics, state environmental contributions, and membership in the professional organization, NAMF, appear to affect a facility's decision to participate in the SGP. We find some evidence that the proportion of emissions potentially subject to the proposed MP\&M regulation is related to a facility's participation decision.

The emissions regression demonstrates a number of intriguing results. First, we do not find robust evidence that the SGP had a significant impact on emission reductions over the entire study period. This result lends itself to the hypothesis in the literature that facilities often join voluntary programs, perhaps with good intentions, but make no real changes in behavior as a direct result of joining the program However, running regressions for two separate time periods tells a more nuanced story. While participants do not appear to initially make use of the program to reduce emissions, they do so in the later

\footnotetext{
${ }^{19}$ Results for the restricted sample are largely consistent with these full sample results. Any results discussed but not reported in the paper are available from the authors upon request.

${ }^{20}$ We compare the emission reductions that are implied by a small, given change in the proportion of MP\&M to total releases, evaluated at the mean for all other variables. This exercise demonstrates that facilities reduce emissions by more in response to the initial regulatory threat than they do in reaction to the incremental increase in its stringency (relative to the level of stringency in the first time period).
} 
years of the program. This finding may be consistent with the idea that relatively clean facilities do not initially change emissions because they have already made use of available abatement opportunities, but with time and increased flexibility (and possibly new information via the SGP) they are able to make further reductions in the later time period.

The regulatory threat faced by the metal-finishing industry is consistently significant across all emission reduction specifications. One may make the case that the threat of regulation induced metal finishers, regardless of SGP participation, to reduce emissions in an attempt to either avoid or prepare for regulation. The split sample results indicate that facilities reacted strongly to both the initial threat of regulation and to an increase in its relative stringency. The fact that a subgroup of the metal-finishing industry joined the SGP in reaction to the regulatory threat and then reduced emissions differentially over time relative to non-participants also points to the possibility that this was related to overarching industry concerns about future regulation.

\section{Acknowledgments}

We thank the editor, two anonymous reviewers, Robin Kime, Bob Benson, George Cushnie, Sarah Stafford, Paul Isely, Hui Li, Jay Shimshack, and participants of the 2005 Heartland Environmental and Resource Economics Workshop for their generous help and useful comments. However, we take responsibility for any mistakes or misstatements that lie within.

\section{References}

[1] W. Anton, G. Deltas, M. Khanna, Incentives for environmental self-regulation and implications for environmental performance, J. Environ. Econ. Manage. 48 (2004) 632-654.

[2] S. Arora, T. Cason, Why do firms volunteer to exceed environmental regulations? Understanding participation in EPA's 33/50 program, Land Econ. 72 (1996) 413-432.

[3] S. Arora, S. Gangopadhyay, Toward a theoretical model of voluntary overcompliance, J. Econ. Behav. Organ. 28 (1995) 289-309.

[4] A. Blackman, J. Boyd, The economics of tailored regulation: will voluntary site-specific performance standards necessarily improve welfare?, Southern Econ. J. 69 (2002) 309-326.

[5] K. Brouhle, C. Griffiths, A. Wolverton, The use of voluntary approaches for environmental policymaking in the US, in: E. Croci (Ed.), The Handbook of Environmental Voluntary Agreements: Design, Implementation and Evaluation Issues, Springer, The Netherlands, 2005.

[6] S. Dasgupta, H. Hettige, D. Wheeler, What improves environmental compliance? Evidence from Mexican industry, J. Environ. Econ. Manage. 39 (2000) 39-66.

[7] R. Davidson, J. MacKinnon, Estimation and Inferences in Econometrics, Oxford University Press, New York, 1993.

[8] J. Davies, J. Mazurek, N. Darnall, K. McCarthy, Industry Incentives for Environmental Improvement: Evaluation of US Federal Initiatives, Global Environmental Management Initiative, 1996

[9] N. Dawson, K. Segerson, Voluntary agreements with industries: participation incentives and with industry-wide targets, Land Econ. 84 (2008) 97-114.

[10] EPA (Environmental Protection Agency), Sector Strategies Program: Announcement of Program Launch, Fed. Register 68 (2003) $23303-23304$.

[11] EPA, Strategic Goals Program: National Performance Goals and Action Plan, Common Sense Initiative, Metal Finishing Sector, 1997.

[12] EPA, The Toxics Release Inventory and Factors to Consider when using TRI Data, 2002.

[13] GAO (General Accounting Office), Status of EPA's Efforts to Reduce Toxic Releases, Washington, DC, 1994

[14] GAO, Information on the Results of Four of EPA's Voluntary Climate Change Programs, Washington, DC, 1997.

[15] B. Goldman, L. Fitton, Toxic Wastes and Race Revisited, United Church of Christ: Center for Policy Alternatives, 1994.

[16] J. Hamilton, Politics and social costs: estimating the impact of collective action on hazardous waste facilities, RAND J. Econ. 24 (1993) 101-125.

[17] J. Hamilton, Pollution as news: media and stock market reactions to the toxic release inventory data, J. Environ. Econ. Manage. 28 (1995) $98-113$.

[18] K. Harrison, Talking with the donkey: cooperative approaches to environmental protection, J. Ind. Ecol. 2 (1999) 51-72.

[19] R. Hartman, Self-selection bias in the evolution of voluntary energy conservation programs, Rev. Econ. Statist. 70 (1988) $448-458$.

[20] I. Henriques, P. Sadorsky, The determinants of an environmentally responsive firm: an empirical approach, J. Environ. Econ. Manage. 30 (1996) 381-395.

[21] M. Horowitz, Electricity intensity in the commercial sector: market and public program effects, Energy J. 25 (2004) 115-137.

[22] Kerr, Greiner, Andersen, and April, Inc., Analysis and Evaluation of the EPA Common Sense Initiative, 1999.

[23] M. Khanna, L. Damon, EPA's voluntary 33/50 program: impact on toxic releases and economic performance of firms, J. Environ. Econ. Manage. 37 (1999) $1-28$.

[24] M. Khanna, W. Quimio, D. Bojilova, Toxics release information: a policy tool for environmental protection, J. Environ. Econ. Manage. 36 (1998) $243-266$.

[25] A. King, M. Lenox, Industry self-regulation without sanction: the chemical industries' responsible care program, Acad. Manage. J. 43 (2000) 698-716

[26] A. King, M. Lenox, M. Barnett, Strategic responses to the reputation commons problem, in: Hoffman, Ventresca (Eds.), Organizations, Policy and the Natural Environment: Institutional and Strategic Perspectives, Stanford University Press, Stanford, CA, 2001.

[27] S. Konar, M. Cohen, Does the market value environmental performance?, Rev. Econ. Statist. 83 (2001) 281-289.

[28] A. Levinson, An industry-adjusted index of state environmental compliance costs, in: Carraro, Metcalf (Eds.), Behavioral and Distributional Effects of Environmental Policy, University of Chicago Press, Chicago, 2001.

[29] S. Lutz, T. Lyon, J. Maxwell, Quality leadership when regulatory standards are forthcoming, J. Ind. Econ. 48 (2000) 331-348.

[30] T. Lyon, J. Maxwell, Environmental public voluntary programs reconsidered, Pol. Stud. J. 35 (2007) 723-750.

[31] J. Maxwell, T. Lyon, Corporate Environmentalism and Public Policy, Cambridge University Press, Cambridge, 2004.

[32] J. Maxwell, T. Lyon, S. Hackett, Self-regulation and social welfare: the political economy of corporate environmentalism, J. Law Econ. 43 (2000) 583-617.

[33] R. Morgenstern, W. Pizer, J. Shih, Evaluating US climate programs: the case of climate wise, in: K. Morgenstern, L. Pizer (Eds.), Reality Check: The Nature and Performance of Voluntary Environmental Programs in the United States, Europe, and Japan, RFF Press, Washington, DC, 2007.

[34] K. Segerson, T. Miceli, Voluntary environmental agreements: good or bad news for environmental protection?, J. Environ. Econ. Manage. 36 (1998) $109-130$.

[35] K. Segerson, J. Wu, Nonpoint pollution control: inducing first-best outcomes through the use of threats, J. Environ. Econ. Manage. 51 (2006) 165-184.

[36] Strategic Goals Program, available at:〈http://www.strategicgoals.org/about〉, 2006.

[37] K. Sunnevag, Voluntary agreements and incentives for innovation, Environ. Planning C 18 (2000) 555-573. 
[38] J. Videras, A. Alberini, The appeal of voluntary environmental programs: which firms participate and why?, Contemporary Econ. Pol. 18 (2000) 449-461.

[39] D. Wallace, Environmental Policy and Industrial Innovation, Strategies in Europe, the US and Japan, Earthscan Publications, London, 1995.

[40] E. Welch, A. Mazur, S. Bretschneider, Voluntary behavior by electric utilities: levels of adoption and contribution of the climate challenge program to the reduction of carbon dioxide, J. Pol. Anal. Manage. 19 (2000) 407-425. 